\title{
TRABALHO ANÁLOGO AO ESCRAVO NA INDÚSTRIA TÊXTIL BRASILEIRA
}

\section{ARTIGO ORIGINAL}

NETO, Dalk Dias Salomão ${ }^{1}$, SOUSA, Nicole Moreira Faria², DENDASCK, Carla Viana $^{3}$, FECURY, Amanda Alves ${ }^{4}$, OLIVEIRA, Euzébio de ${ }^{5}$, DIAS, Claudio Alberto Gellis de Mattos $^{6}$

NETO, Dalk Dias Salomão. Et al. Trabalho Análogo Ao Escravo Na Indústria Têxtil Brasileira. Revista Científica Multidisciplinar Núcleo do Conhecimento. Ano 06, Ed. 05, Vol. 13, pp. 28-46. Maio de 2021. ISSN: 2448-0959, Link de acesso: https://www.nucleodoconhecimento.com.br/ciencias-sociais/textil-brasileira, DOI: 10.32749/nucleodoconhecimento.com.br/ciencias-sociais/textil-brasileira

\section{RESUMO}

O instituto da escravidão está presente na humanidade desde os primórdios da existência do ser humano. A escravidão no Brasil sustentou a economia por séculos. Milhões de africanos foram retirados da sua terra natal e colocados em condições degradantes de vida e trabalho. O processo da abolição da escravidão foi moroso e paulatino. Foram séculos de muita luta e sofrimento para que o mundo começasse a perceber o mal que a escravidão representa. Mesmo após a abolição da escravidão

\footnotetext{
${ }^{1}$ Advogado, Bacharel em Direito (CEAP - Centro de Ensino Superior do Amapá), Especialista em direito trabalhista e processo trabalhista pela instituição Damásio educacional.

${ }^{2}$ Advogada, Bacharel em Direito (CEAP - Centro de Ensino Superior do Amapá), especialista em Direito Processual Civil pela instituição Damásio Educacional.

${ }^{3}$ Teóloga, Doutora em Psicanálise Clínica. Atua há 15 anos com Metodologia Científica ( Método de Pesquisa) na Orientação de Produção Científica de Mestrandos e Doutorandos. Especialista em Pesquisas de Mercado e Pesquisas voltadas a área da Saúde. Doutoranda em Comunicação e Semiótica (PUC SP).

${ }^{4}$ Biomédica, Doutora em Doenças Tropicais, Professora e pesquisadora do Curso de Medicina do Campus Macapá, Universidade Federal do Amapá (UNIFAP), Pro-Reitora de Pesquisa e Pós-Graduação (PROPESPG) da Universidade Federal do Amapá (UNIFAP).

${ }^{5}$ Biólogo, Doutor em Doenças Tropicais, Professor e pesquisador do Curso de Educação Física, Universidade Federal do Pará (UFPA).

${ }^{6}$ Biólogo, Doutor em Teoria e Pesquisa do Comportamento, Professor e pesquisador do Curso de Licenciatura em Química do Instituto de Ensino Básico, Técnico e Tecnológico do Amapá (IFAP) e do Programa de Pós Graduação em Educação Profissional e Tecnológica (PROFEPT IFAP).

RC: 86328
}

Link de acesso: https://www.nucleodoconhecimento.com.br/ciencias-sociais/textil-brasileira 
era comum ver o trabalhador preso ao campo por dívidas, ou por leis que davam poderes aos empregadores em relação ao empregado. $O$ objetivo desta pesquisa foi analisar as condições de trabalho análogo ao escravo na indústria têxtil brasileira. Ela foi realizada com revisão bibliográfica e análise qualitativa. Devido a sua nova roupagem o trabalho escravo contemporâneo tornou-se invisível por algum tempo. Os fatores que tornam possível a prática desse crime, mesmo que em dias atuais, ele é basicamente relacionado a um tripé: impunidade, pobreza e lucro. A situação de miséria da população mais carente os força a se submeter a tipos de trabalhos em condições sub-humanas. Estes trabalhadores da indústria têxtil são principalmente imigrantes de países vizinhos, subdesenvolvidos, da América Latina. O Brasil foi um dos primeiros países no mundo a reconhecer este tipo de trabalho, e que de forma conjunta com a Organização Internacional do Trabalho (OIT) e ostras entidades não governamentais procuram combater tal prática criminosa em seu território.

Palavras-chave: Escravidão, Legislação, Combate, Indústria.

\section{INTRODUÇÃO}

O instituto da escravidão está presente na humanidade desde os primórdios da existência do ser humano. Embora tenha apresentado significados, formas e objetivos diferentes ao longo da história, a escravidão sempre foi marcada pela dominação de uns pelos outros (Mota e Ramos, 1999)

Para Oliveira (2011) a relação entres os homens se iniciou na fase pré-histórica, devido as precárias condições de vida e a necessidade de caça, pesca e coleta frutas. E foi por meio da troca de experiências e a colaboração entre os indivíduos que surgiram as primeiras tribos.

O instituto da escravidão acompanha o homem desde o princípio da raça humana, como já foi dito, possuindo provas da sua existência em diversos momentos da humanidade e em inúmeras formas. Por exemplo, na Bíblia sagrada (principal livro dos cristãos), encontramos numerosos casos de escravidão citados ao longo dos evangelhos. A escravidão, nessa época, era baseada na servidão por dívidas ou de 
trabalho decorrente da subjugação do vencido pelo vencedor, dentre outras (Oliveira, 2011).

Com a utilização da escravidão para os trabalhos mais pesados, povos como os gregos conseguiram desenvolver a filosofia $e$ as artes como ninguém. Concomitantemente com a produção comercial, houve uma grande expansão da produção artesanal e agropecuária canalizada pelo comércio de exportação e importação (Oliveira, 2011).

Para Silva (2010), assim como na Grécia, Roma utilizou-se da mão de obra escrava, e foi durante o período do império que a escravidão teve seu ápice, chegando a um total de $30 \%$ da sociedade Romana.

Havia várias formas de se tornar escravo em Roma, em regra todo filho de mãe escrava também era escravo. Outra forma de se escravizar alguém era por meio da guerra, sendo os prisioneiros obrigados ao trabalho forçado, a escravidão também era usada como forma de penalizar indivíduos, como em caso de deserção do exército ou inadimplência de dividas (Silva, 2010).

A sociedade da Idade Média era formada pelos senhores feudais, o clero e os servos. Neste período a escravidão não foi o principal meio de força de trabalho, sendo os servos substitutos dos escravos, sofrendo péssimas condições de vida e trabalho (Silva, 2010).

Apesar de os servos não serem considerados objetos, a sua situação jurídica não era tão diferente dos escravos, já que eles eram tratados como meros acessórios da terra, sofrendo imposições de ordem pessoal, não tendo seu direito de ir e vir garantido e até mesmo proibição de contrair matrimônio sem autorização (Silva, 2010).

Trazendo o foco para o nosso país é importante salientar que a escravidão marcou presença na evolução histórica dessa grande porção de terra. Inicialmente conhecida como Santa Cruz de Cabrália e posteriormente de Brasil, foi colonizada por portugueses, que ao chegarem aqui no ano de 1500, trouxeram consigo a escravidão 
em larga escala, iniciando com os nativos, tupis e guaranis em sua maioria e posteriormente os negros africanos (Silva, 2010).

Para obter êxito na busca das matérias primas para a metrópole, os portugueses iniciaram a colonização valendo-se da escravidão como base de extração. Primeiramente usaram a mão de obra nativa, fazendo o escambo com os mesmos que, em troca das especiarias e metais, deixavam para os índios objetos de valor irrelevante como espelhos e pentes (Oliveira, 2011).

A relação da coroa portuguesa e dos nativos no início foi bastante pacífica, todavia, após os portugueses decidirem ocupar o território para desenvolver a exploração econômica, as relações mudaram. A partir de então os colonizadores começaram a expulsar os nativos das suas terras e a subjugá-los ao trabalho escravo, os quais sofreram com a exploração física e novas doenças trazidas pelo homem branco (Gorender, 1985).

Os povos indígenas sofreram durante muito tempo com a escravidão, contudo, esta situação não durou por muito tempo, haja vista vários fatores que frearam a exploração do nativo, como a baixa densidade populacional dos povos indígenas; as tribos que se tornavam pouco amistosas quando percebiam a sua escravização; a população indígena que acabou sendo dizimada em decorrência da exploração e de doenças até então desconhecidas, assim como a proteção recebida pelos jesuítas (Campos, 2015).

A mesma proteção dada aos indígenas pelos jesuítas não foi dada aos negros, dessa forma a sua escravização foi praticamente um consenso entre igreja e coroa (Fausto, 2004). Uma das principais justificativas para escravizar o negro africano foi a de que essa prática já era comum na África, baseados também em teorias cientificas que afirmavam a inferioridade da raça negra, pois demonstravam-se pessoas de baixa inteligência e emocionalmente instáveis, destinadas biologicamente à sujeição, criando uma das maiores formas de preconceito já vista (Mattos, 2015).

A escravidão no Brasil sustentou a economia por séculos. Milhões de africanos foram retirados da sua terra natal e colocados em condições degradantes de vida e trabalho. RC: 86328

Link de acesso: https://www.nucleodoconhecimento.com.br/ciencias-sociais/textil-brasileira 
Segundo (Soares, 1860), registrou-se a entrada de aproximadamente 371.615 escravos entre 1840 e 1851 no país.

Inicialmente, a mão de obra escrava e a economia brasileira eram concentradas no campo, na agricultura, mais especificamente nas lavouras de cana de açúcar localizadas no Nordeste, sendo uma forma encontrada pela coroa de colonizar essa parte do "novo mundo". É importante demonstrar que no século XVIII, com a expansão progressiva da colonização e descoberta de novos espaços no interior do país, descobriu-se o grande potencial minerador das terras, criando-se um mercado intenso da extração de minérios, como do ouro, onde a mão de obra escrava possibilitou tal atividade (Campos, 2015).

E foi nesse ritmo que a escravidão marcou de forma negativa não só o mundo, mas também o Brasil. A única justificativa da importação do negro era o trabalho. Eles trabalhavam horas a fio, de quinze a dezoito horas diárias, sofriam violência física e psicologia diariamente e eram tratados como objetos (Pinsky, 1992).

O processo da abolição da escravidão foi moroso e paulatino. Foram séculos de muita luta e sofrimento para que o mundo começasse a perceber o mal que a escravidão representa. Existem vários momentos importantes que representam essa mudança de pensamento: a proclamação de independência dos Estados Unidos, que tinha como base a declaração dos direitos do homem; a Revolução Francesa em 1789 que exaltou os princípios da liberdade, igualdade e fraternidade. Vale ressaltar também a Revolução Inglesa que, com o advento da máquina, mostrou que a produção poderia aumentar mesmo usando o trabalho livre (Montenegro, 1997).

Diante disso, os comerciantes e produtores tiveram que procurar uma forma de substituir a mão de obra escrava. Por exemplo, nas lavouras cafeeiras o trabalho escravo foi substituído por imigrantes europeus, no chamado sistema de colonato (estímulo do estado brasileiro) que trabalhavam mediante remuneração, estipulada na porcentagem da produção do café (Silva, 2010).

Mesmo após a abolição da escravidão era comum ver o trabalhador preso ao campo por dívidas, ou por leis que davam poderes aos empregadores em relação ao RC: 86328

Link de acesso: https://www.nucleodoconhecimento.com.br/ciencias-sociais/textil-brasileira 
empregado, através de obrigações contratuais, como por exemplo duras penas, como a prisão do trabalhador que se ausentasse da fazenda sem motivo justo ou que, permanecendo na propriedade, se recusasse a trabalhar (Silva, 2010).

Dessa forma, entende-se que a abolição da escravidão no Brasil, pela Lei Aurea, não libertou de fato os escravos, pois havia a existência de uma sociedade extremamente racista e preconceituosa, resultando, assim, nas práticas atuais análogas à escravidão

\section{OBJETIVO}

Analisar as condições de trabalho análogo ao escravo na indústria têxtil brasileira.

\section{MÉTODO}

A pesquisa foi realizada com revisão bibliográfica e análise qualitativa.

Segundo Lima e Mioto (2007): "[...]construir um processo de pesquisa, relativas à definição dos procedimentos metodológicos que orientarão tal processo, baseia-se na observação de que vários relatos de pesquisas".

A pesquisa qualitativa trabalha com valores, atitudes e a relação entre processos e fenômenos, não medidos numericamente (Gerhardt e Silveira, 2009).

\section{RESULTADOS E DISCUSSÃO}

\section{TRABALHO ANÁLOGO AO ESCRAVO}

A existência do trabalho análogo ao escravo pode ser explicada pelo simples fato da não superação do antigo sistema escravocrata, devido ao seu enraizamento cultural ao longo dos séculos, mesmo após a sua proibição. Além disso, escravidão contemporânea é baseada por um tripé: impunidade, ganância e pobreza, se tornando necessário, não apenas combater esse crime como qualquer outro, e sim rever nosso sistema de Justiça, padrões de consumo e modelos de desenvolvimentos (Miranda e Oliveira, 2010). 
Portanto, o mundo e seus esforços ainda não conseguiram extinguir o trabalho escravo, demonstrando-se como uma tarefa árdua, principalmente pela cultura e pela falta de compaixão entre os homens. Devendo dessa forma, tanto os Estados como a sociedade em geral ficar em vigilante para com esse tipo de absurdo.

\section{PRINCÍPIOS PROTETORES DO TRABALHO}

Os princípios jurídicos são definidos como um conjunto de padrões de conduta que se apresentam no ordenamento jurídico. Os princípios, assim como as regras, são normas. Pode-se afirmar que toda ciência é fundada em princípios, sendo assim, o direito não foge dessa regra (Saraiva, 2012).

No pensamento de Martins (2011, p. 62) os princípios formam os pilares do direito, sua base, sendo que os princípios têm um grau de abstração muito maior do que a norma, cabendo sua aplicação a casos concretos (Martins, 2011).

Os princípios são explicados por duas correntes, a jusnaturalista e o positivismo jurídico, sendo que a primeira põe os princípios acima do direito positivo, prevalecendo assim sob as leis. Já para a segunda os princípios seriam integradores da lei, preenchendo as lacunas existentes nela (Nascimento, 2010).

Não fugindo a regra o direito do trabalho é formado por um conjunto de princípios e regras que buscam assegurar melhores condições de trabalho aos obreiros, por meio de proteção.

É importante mencionar um princípio que apesar de não ser da seara trabalhista é de extrema importância para o ordenamento jurídico como um todo, o princípio da dignidade da pessoa humana. Tal princípio possui um valor moral e espiritual inerente à pessoa, portanto, cada pessoa é dotada desse preceito, e tal constitui o princípio máximo do estado democrático de direito.

O princípio da proteção é o mais amplo e de maior importância no Direito do Trabalho. Este princípio é aquele que norteia todo Direito do Trabalho, objetivando proteger a parte mais frágil na relação jurídica, o trabalhador, que se vê desprotegido face ao RC: 86328

Link de acesso: https://www.nucleodoconhecimento.com.br/ciencias-sociais/textil-brasileira 
empregador. Ele procura dar maiores condições a parte hipossuficiente relação, o empregado. Portanto, ele propicia a criação de mecanismos para diminuir a desigualdade entre partes, impedindo a exploração do trabalho e garantindo o bemestar social dos obreiros (Saraiva, 2012).

Tal princípio é normalmente dividido em três: o "in dubio pro operário", o da aplicação da norma mais favorável e o da aplicação da condição mais benéfica. O princípio "in dubio pró-operário", afirma que diante de duas ou mais interpretações viáveis, devese escolher a mais favorável ao trabalhador, desde que não contrarie a clara manifestação do legislador, nem se trate de matéria proibitória. O princípio da norma mais favorável, afirma que no caso de conflito entre duas ou mais normas aplicáveis no caso, deve-se optar por aquela mais vantajosa ao trabalhador. Por fim, o princípio da condição mais benéfica, determina a permanência de condições mais vantajosas para o trabalhador, mesmo que vigore norma jurídica imperativa estipulando o contrário (Saraiva, 2012; Mattos, 2015).

Os direitos trabalhistas, em regra, são irrenunciáveis pelo trabalhador. Este princípio extremamente importante para a proteção do hipossuficiente, pois muitas vezes o empregador, através da coação, ludibria ou forço o empregado a decidir contra a sua vontade, abdicando de direitos já conquistados (Rodriguez, 2015). Ou seja, em regra os direitos trabalhistas não podem ser renunciados pelo trabalhador, por exemplo, não se pode abrir mão das férias, caso isso ocorro tal ato será considerado nulo (Martinez, 2015).

O Princípio da Primazia da Realidade aduz que as relações jurídicas trabalhistas se definem pela situação de fato, isto é, pela forma como se realizou a prestação de serviços, pouco importando o nome que Ihes foi atribuído pelas partes (Saraiva, 2012).

Um exemplo claro é quando através de depoimento de testemunhas fica provado o não fornecimento de equipamento individual de trabalho (EPI), apesar de haver assinatura de cautelas de entregas. Portanto, fica claro que se pode provar a verdade 
dos fatos por meio testemunhas, por exemplo, prevalecendo tal prova ao documento escrito, se comprovado a autenticidade do testemunho.

\section{CONSIDERAÇÕES GERAIS DO TRABALHO ANÁLOGO AO ESCRAVO}

Anteriormente os escravos eram vistos como objetos e hoje não mais. Porém, apesar de atualmente serem vistos como pessoas dotadas de personalidade ainda são subjugados a degradantes condições de vida e trabalho (Mattos, 2015).

Vale ressaltar que se chama "trabalho análogo ao escravo", uma vez que, o trabalho escravo, propriamente dito, foi extinto. Todavia, apesar de todos os esforços, tais práticas escravagistas não sumiram por completo.

existência do trabalho análogo ao escravo pode ser explicada pelo simples fato da não superação do antigo sistema escravocrata, devido ao seu enraizamento cultural ao longo dos séculos, apesar da implantação do trabalho assalariado. Além disso, escravidão contemporânea é baseada por um tripé: impunidade, ganância e pobreza, tornando-se necessário, não apenas combater esse crime como qualquer outro, e sim rever nosso sistema de Justiça, padrões de consumo e modelo de desenvolvimento (Miranda e Oliveira, 2010).

O instituto da escravidão na atualidade possui uma nova roupagem, havendo diversas denominações para o trabalho análogo ao escravo: trabalho escravo contemporâneo; trabalho em condições subumanas, escravidão por dívida, trabalho forçado, super exploração do trabalho, nova escravidão entre outras, trabalho forçado, trabalho degradante entre outros (Cristova e Goldschmidt, 2012).

As várias denominações expostas acima são devidas há uma falta de consenso em torno do seu conceito, assim como nos critérios utilizados para a sua caracterização do instituto. Devido a isso, existe uma variação de elementos na sua conceituação, assim como nos termos usados, para se referir a este tipo de exploração da mão deobra do trabalhador (Cristova e Goldschmidt, 2012). 
Diversos autores já se posicionaram a cerca desse assunto, sendo que não houve um entendimento uniforme entre os pensamentos. Todavia, ficou claro em todos o mesmo sentimento de repulsa por essas formas desumanas de tratar as pessoas, sujeitando o trabalhador a condições sub-humanas (Brito Filho, 2004).

A realidade do trabalhador escravizado é a de alguém que não tem opção de

escolha, não possuindo direitos. Tais trabalhadores costumam ser aliciados em locais distantes do local de trabalho, sendo-lhes prometido um bom trabalho, com carteira assinada, remuneração generosa entre outros benefícios. Todavia, quando o trabalhador chega ao local de trabalho se depara com uma realidade completamente diferente da prometida, tendo na maioria das vezes que arcar com os gastos da viagem, moradia e alimentação (Prado, 2005).

O termo "trabalho escravo" facilita o entendimento pelo público mais leigo, pois possui Características que se assemelham aos conceitos adotados pela Organização Internacional do Trabalho. Sendo que tal conceito aproximasse muito do "trabalho forçado (Audi, 2006).

Diante desses conceitos, podemos perceber que o trabalho análogo ao escravo existe, muita das vezes, devido a hipossuficiência dos trabalhadores, que em busca do mínimo para o seu sustento e de sua família, acabam deixando de lado a sua própria dignidade, submetendo-se ao trabalho humilhante (Campos, 2015).

A dificuldade em caracterizar o trabalho em condições análogas à de escravo não apresentasse apenas no meio acadêmico, envolve agentes públicos como juízes, promotores e funcionários das delegacias do trabalho. Essa dificuldade tem consequências grandiosas, pois acabada atrapalhando a caracterização e a tipificação do ato, tornando-se difícil perceber o crime em si.

Portanto, baseado nos conceitos acima e em pesquisas, pode-se definir trabalho em condições análogas à condição de escravo como o exercício do trabalho humano com restrição, em qualquer forma, podendo ser da liberdade do trabalhador, não tendo os seus direitos mínimos para o resguardo da dignidade da pessoa humana. 
O reconhecimento oficial do trabalho análogo ao de escravo no Brasil deu-se, em 1995, apesar de diversas denúncias a OIT (Organização Internacional do Trabalho) ao longo dos anos. Apesar desse agravante, o Brasil foi um dos primeiros países do mundo a assumir internacionalmente a existência da escravidão contemporânea (Miranda e Oliveira, 2010).

Como afirma o Ministério do Trabalho e Emprego (MTE), o trabalho análogo ao escravo é uma realidade bastante presente no país, como demonstram os dados do próprio MTE, os quais revelam que entre 1995 e 2010, 36.759 trabalhadores foram retirados de condições análogas à de escravo (Mte, 2018).

Segundo a Organização Internacional do Trabalho, a principal causa da escravidão é a exploração econômica dos trabalhadores, estima-se cerca de quase oito milhões de pessoas vivendo nessas condições no mundo. No Brasil, segundo dados do governo brasileiro, fornecidos através de pesquisa da Comissão Pastoral da Terra, existem cerca de vinte e cinco mil pessoas trabalhando em condições análogas às de escravo. Sobre esse montante a maior concentração está localizada nos estados do Norte e do Centro-Oeste, sendo que $90 \%$ do total é composto por analfabetos, $90 \%$ iniciaram com exploração do trabalho infantil, e $80 \%$ sequer possuem certidão de nascimento (Simón e Melo, 2007).

O Brasil reconhecidamente pela OIT foi um dos primeiros países a conhecer e combater o trabalho análogo ao escravo. Dessa forma, a sua criminalização se deu através, do art. 149 do Código Penal Brasileiro, que posteriormente foi alterado pela Lei $n^{\circ}$ 10.803/2003 (Brasil, 1940; 2017) Sendo muito importante frisar que no Brasil, através do artigo 149 do CP, o "trabalho análogo ao escravo" é um gênero, possuindo outras espécies, como o trabalho forçado e o degradante (Brasil, 2017).

A partir da alteração do artigo 149 do CP pela lei no 10.803, de 11 de dezembro de 2003, o combate ao trabalho análogo ao escravo deu um grande avanço, pois, tornouse mais fácil a caracterização de tal delito. 
O trabalho análogo ao escravo é um gênero, possuindo algumas espécies. Para alguns estudiosos na área essas espécies variam, podendo ser trabalho forçado, trabalho exaustivo, trabalho degradante e por dívida.

Já Simón e Melo (2007) usam a nomenclatura "trabalho prestado em condições análogas à de escravo", sendo dividida em três espécies: o trabalho forçado, o trabalho em condições degradantes e a servidão por dívida. Tais formas ilícitas de trabalho não puíssem efeitos jurídicos, pois são nulas, sendo que o combate dessas práticas, segundo o direito brasileiro, é realizado pelo Direito Penal.

O estudioso Greco (2008) afirma que a o trabalho escravo ocorre atualmente quando uma pessoa obriga outra a executar trabalhos forçados, exigindo jornadas exaustivas, sujeitando o trabalhador a condições degradantes, ou, restringindo a sua locomoção em razão de dívida contraída.

Silva (2010)demonstra ainda que a coação sofrida pelo trabalhador para ele não deixar o trabalho pode ter várias naturezas, de ordem moral ou psicológica, como ocorre nas ameaças a integridade mental do trabalhador, também a física, não podendo o trabalhador deixar o local de trabalho, pois caso contrário sofrerá castigo físico, muita das vezes havendo vigilância armada.

Para Araújo Júnior (2006), o trabalho em condições degradantes caracteriza-se pelo não cumprimento das normas básicas de segurança e saúde no trabalho por parte do empregador, que não disponibiliza os exames médicos do trabalhador, não garante equipamentos de proteção individuais (EPI), nem local para proteção dos trabalhadores contra as intempéries, além de manter alojamentos sem as menores condições de higiene e sem alimentação adequada.

Há também o trabalho exaustivo, conhecido como trabalho extenuante, na qual o trabalhador é testado a condições de trabalho além dos limites de tempo permitidos pela legislação, podendo trazer muitos danos para o trabalhador. A jornada exaustiva pode ser conceituada como aquela que ultrapassa os limites do princípio da dignidade da pessoa humana. Tal jornada extenuante não significa apenas ao número exagerado de horas, mas também ao ritmo inadequado (Campos, 2015). RC: 86328 Link de acesso: https://www.nucleodoconhecimento.com.br/ciencias-sociais/textil-brasileira 
O estudioso Proner (2010) afirma que uma jornada exaustiva de trabalho acaba influenciando negativamente o trabalhador, pois o priva de momentos de lazer e educação, convívio social e com a família, podendo acarretar em doenças psicológicas e físicas, pois torna-se propenso a adquirir uma doença ocupacional.

Segundo Bales (2001) a escravidão por dívida é uma forma moderna de exploração do trabalho humano, sendo a mais comum no mundo e especialmente no Brasil. Tal condição se dá quando a pessoa é empenhada a trabalhar para outra em virtude de empréstimo contraído. São oferecidos contratos de trabalho com supostas garantias trabalhistas, geralmente em locais mais afastados geograficamente, em fazendas ou fábricas, todavia, ao chegar no local a realidade é outra, trabalhadores enganados acabam sendo escravizados, servindo o contrato apenas para ludibriar o trabalhador e levá-lo ao erro.

Segundo Audi (2006), podemos concluir que apesar de inúmeras maneiras apresentadas, todas as modalidades de trabalho análogo ao escravo têm sempre em comum duas características: o uso da coação e a negação da liberdade.

\section{FATORES QUE CONTRIBUEM PARA O TRABALHO ANÁLOGO AO ESCRAVO NO BRASIL}

Em 1988 houve a publicação da Lei Áurea, que aboliu a escravidão no país. Todavia, não foi eficiente para erradicá-la, por diversos fatores sociais, como a desqualificação da mão-de-obra dos "ex escravos" (Cristova e Goldschmidt, 2012).

A autora Monteiro (2011) observou fatores imprescindíveis para a permanência do trabalho escravo no país, definindo-os em um tripé: impunidade, pobreza e lucro.

Quanto ao lucro, remete-se aos beneficiários que utilizam o trabalho escravo como uma maneira de obter lucros altos, de forma mais fácil, já que não se sentem obrigados a cumprir as legislações trabalhistas (Monteiro, 2011).

No que concerne à miséria, é a principal responsável por fazer com que muitos trabalhadores se submetam a trabalho com condições análogas a de escravo, uma 
vez que estão dispostos a concordar até mesmo com propostas desumanas com o objetivo de saírem da extrema pobreza e sustentar suas famílias (Monteiro, 2011).

De acordo com a Organização Internacional do Trabalho, a causa predominante da escravidão é a exploração econômica. E em conjunto com essa informação a globalização nos mercados podem ser a razão preponderante, posto que gera uma grande concorrência, fazendo com que os fabricantes/produtores se adequem ao sistema, produzindo com custos baixíssimos (Cristova e Goldschmidt, 2012).

Com relação aos fatores preponderantes para a existência do trabalho escravo nas áreas rurais, Silva (2009) explana que influenciam a região pobre do trabalhador rural, sendo uma área com uma grande parcela desempregados que são convencidos pelo contratante mediante falsas promessas, sem contrato de trabalho formal ou qualquer norma estabelecida pela Consolidação das Leis do Trabalho (CLT).

No que se refere ao conhecimento anteriormente explanado de que decisões judiciais favoráveis aos empregadores contribuem para a manutenção de mão-de-obra escrava no Brasil, complementa o pensamento de Silva (2009), de que não há na legislação pena rigorosa para punir os responsáveis pela exploração de trabalho análogo a escravo.

Sendo assim, com a ausência de legislação satisfatória, a sensação produzida é de impunidade, a qual passa a transmitir a ideia de que os malfeitores podem continuar com a mesma conduta criminosa, já que não serão consequências graves pelos seus atos (Silva, 2009).

Para a autora Damião (2014), as causas do trabalho escravo no país são, principalmente, a má distribuição de renda e educação deficiente. Deste modo, a miséria gerada pela injusta distribuição de renda, como dito anteriormente, faz com que os labutadores se sujeitem às condições desumanas do trabalho escravo. Já a educação insatisfatória, facilita para que os trabalhadores sejam enganados, de maneira que não são capazes de lutar por seus direitos trabalhistas. 
Nos últimos anos foram criados vários mecanismos de combate, por exemplo, a "lista suja" e planos nacionais de erradicação ao trabalho análogo ao escravo. Todavia, apesar de todo esse histórico de combate e fiscalização, no ano de 2017, ocorreu no Brasil a reforma da lei trabalhista, pela lei 13.467/17, que trouxe um retrocesso no assunto, banalizando a prática do crime e dificultando a prevenção (Costa, 2015).

\section{FORMAS DE COMBATE E ERRADICAÇÃO AO TRABALHO ESCRAVO CONTEMPORANEO}

No Brasil, o enfrentamento do referido crime ganhou força nas últimas décadas, apesar do atraso vivenciado pela recente reforma trabalhista. Sabe-se da existência de inúmeros casos de pessoas que vivem em condições análogas à escravidão que burlam a precária fiscalização do Estado (Oliveira, 2011).

O combate e a erradicação do trabalho escravo contemporâneo mostram-se muito mais difíceis do que parecem, visto que não se resolve a situação simplesmente tirando o trabalhador da situação precária e punindo os infratores. O que de fato deve ser feito é uma mudança do modelo de desenvolvimento capitalista que, por intermédio da busca do lucro, acaba com a vida de famílias inteiras (Miranda e Oliveira, 2010).

Existem várias formas de combate ao trabalho análogo ao escravo, tanto judiciais como extrajudiciais. Porém, são as políticas públicas que influenciam na reeducação e mudança cultural da sociedade é o principal meio de vencer essa mazela social (Silva, 2010).

No Brasil há uma cooperação conjunta de vários órgãos públicos na tentativa de erradicar a exploração do trabalho análogo ao de escravo, quais sejam: Instituto Nacional de Colonização e Reforma Agrária (INCRA); Polícia Federal (PF); Polícia Rodoviária Federal (PRF); Ministério do Trabalho e Emprego (MTE) e Ministério Público (MP). Sendo importante salientar que o trabalho isolado de apenas uma instituição não se mostra eficaz. Outra maneira importante de combater passa pela 
própria sociedade que, por meio de denúncias anônimas, podem dar respostas mais rápidas para solucionar tais problemas.

Contrários à prática de trabalho escravo contemporâneo é importante salientar alguns autores, como o Ministério Público do Trabalho e da Justiça do Trabalho, que possui um papel muito importante, por meio de medidas de repressão, tendo como exemplo as Ações Civis Públicas por Danos Morais, que busca a reparação pecuniária.

É importante ressaltar a criação do Plano Nacional pela Erradicação do Trabalho Escravo, que foi elaborado pela Comissão Especial do Conselho de Defesa dos Direitos da Pessoa Humana (CDDPH), o qual atua em âmbito nacional. O referido plano reúne entidades e autoridades relacionadas ao tema, que buscam a criação e manutenção de uma política pública duradoura, sendo fiscalizada por órgãos ou fórum nacional dedicado à repressão do trabalho escravo.

Outra estratégia utilizada para o combate de tal crime no Brasil origina-se através da Comissão Nacional para a Erradicação do Trabalho Escravo (CONATRAE), que articula e executa iniciativas. Segundo Oliveira (2011), esse órgão foi criado em agosto de 2003 e é formado por um colegiado vinculado à Secretaria Especial dos Direitos Humanos da Presidência da República, tendo como principal função monitorar a execução do Plano Nacional para a Erradicação do Trabalho Escravo.

Outra forma de embate é o Pacto Nacional pela Erradicação do Trabalho

Escravo no Brasil. Esta iniciativa é baseada em esforços internacionais, por meio da influência da OIT (Organização Internacional do Trabalho, órgão da ONU). O pacto supracitado funciona com a colaboração de órgãos fiscalizadores do Estado, que buscam localizar e punir o trabalho escravo contemporâneo. Segundo Miranda e Oliveira (2010) esse esforço vem dando resultados, recebendo apoio de representantes de empresas que, somadas, significam mais de $25 \%$ do PIB nacional. 
Uma das formas de combate ao trabalho análogo ao escravo mais conhecida no Brasil é a "lista suja". Esta ferramenta funciona da seguinte maneira: criou-se um Cadastro de Empregadores que obrigam trabalhadores a se submeter a condições análogas às de escravo. A referida lista é um mecanismo público de transparência do Estado brasileiro, criada em 2003, que busca divulgar os nomes de pessoas físicas ou jurídicas que foram flagradas utilizando a mão de obra escrava (Mattos, 2015).

O cadastro supracitado foi regulamentado pela portaria ํㅜ 1.234 de 2003 do Ministério do Trabalho e Emprego, que posteriormente foi substituída pela portaria interministerial n. .2 de 12 de maio de 2011, documento este que encontrasse em vigor (Campos, 2015). Percebe-se então que essa forma de combate se torna de estrema importância na luta contra ao trabalho escravo contemporâneo, sendo a lista de empregadores considerada pela $\mathrm{ONU}$, modelo de referência no mundo.

No mesmo sentido da "lista suja" foi criada a Lei no 14.946/2013 pelo Estado de São Paulo, que tem como o objetivo buscar e barrar as atividades de empresas que tenham em sua cadeia produtiva o uso de empregados em condições análogas à escravidão. A referida lei descendeu de um projeto de lei no 1.034 de 2011 de autoria do Deputado Carlos Bezerra Junior, tendo uma peculiaridade, pois é direcionada a realidade dos trabalhadores da indústria têxtil paulista (Mattos, 2015).

A forma de combate expressada nesta lei é baseada na cassação da inscrição estadual de contribuinte do Imposto sobre Circulação de Mercadorias e Serviços (ICMS). Dessa forma, o empregador que se beneficiar direta ou indiretamente de trabalho análogo ao de escravo tem seu registro cassado, além de que sofrerá restrições da legislação própria do tema, tal punição apresenta-se no artigo $1 \stackrel{\circ}{\text { da }}$ referida lei (Dou, 2013).

O artigo $4^{\circ}$ da lei ํo 14.946 de 2013 do Estado de São Paulo, uma vez efetuada a cassação da inscrição do ICMS, a pessoa jurídica infratora fica impossibilitada de exercer atividades no mesmo ramo, ainda que em local distinto, e os sócios ficam impedidos de abrir outras empresas de mesma atividade, pelo prazo de 10 anos, a contar da cassação (Campos, 2015). 
O trabalho escravo, apesar de abolido a centena de anos permanece presente na sociedade, contrariando os direitos humanos. A escravidão contemporânea, diferente de antigamente, não se baseava mais na propriedade do senhor sobre os escravos, muito menos no negócio de compra e venda de trabalhadores, mas sim no controle excessivo do empresário sobre o trabalhador, usando de meios como a coação e coerção, com o objetivo de aumentar seus lucros.

Um dos setores da economia na qual tal prática criminosa se mostra muito presente é o têxtil. Existente nas grandes capitais mundiais, o trabalho escravo deixou de ser predominantemente rural e se apresenta como urbano, principalmente nas fábricas de costuras.

$\mathrm{Na}$ realidade do trabalho escravo urbano, grandes números de pessoas deixam suas casas, abandonando família em busca de melhores condições de vida e acabam por se submeter a práticas análogas à escravidão, principalmente por necessidade, nas grandes fabricas têxtil (Campos, 2015).

Por conseguinte, a indústria têxtil é uma das grandes exploradoras da mão de obra escrava contemporânea. Segundo Mattos (2015), a indústria têxtil beneficia diretamente o trabalho escravo contemporâneo, especialmente pelo fato de sua produção ser de curto prazo, sendo a China uma das principais utilizadoras desse tipo de mão de obra, tornando-a extremamente competitiva neste mercado.

Valendo-se dessa situação de vulnerabilidade do ser humano, a "indústria da moda" usa o trabalho análogo ao escravo como forma de baixar seus custos de produção. As indústrias têxteis, por meio da terceirização de suas atividades, acabam contribuindo para a precarização das condições de trabalho, delegando suas atividades para oficinas de costuras informais ou até mesmo caseiras.

Esse sistema de exploração de mão de obra escrava, usada pelas indústrias têxtis, é conhecida como sweating system, sendo a forma mais encontrada de escravidão contemporânea no meio urbano ao redor do mundo. O termo em inglês, conhecido também como "sistema de suor" (tradução nossa), faz menção a locais de trabalho realizados em locais informais que acabam se confundindo com residências e RC: 86328

Link de acesso: https://www.nucleodoconhecimento.com.br/ciencias-sociais/textil-brasileira 
oferecem condições extremas de trabalho e salários miseráveis (Cristova e Goldschmidt, 2012).

Vale ressaltar que os principais sujeitos capitados por esses sistemas são os estrangeiros, geralmente de países mais subdesenvolvidos, como alguns asiáticos e latino-americanos. Pois, devido à condição de miserabilidade que se encontram em seus países natais, acabam atraídos por ofertas falsas de empregos. Dessa forma, cria-se um ambiente pelo mercado capitalista, no qual as empresas buscam a terceirização como forma de diminuição de custo e para aumentar a competitividade. O trabalhador sujeita-se ao trabalho em condições análogas ao escravo, por necessidade, dando margem para a criação de pequenas oficinas de costura, que praticam a exploração, por meio do trabalho forçado e degradante (Palo Neto, 2008).

As condições de trabalho análogo ao escravo em que se encontram os trabalhadores da indústria da moda no Brasil fazem parte do trabalho escravo contemporâneo urbano, um pouco menos comum do que o rural, porém sendo do mesmo modo um grande problema.

Essa rede de escravidão no meio urbano está ligada diretamente com a imigração de estrangeiros, advindo principalmente de países mais pobres da América Latina. Mão de obra essa que é aliciada para trabalhar nas fábricas de confecções de roupas. Fato este que não exclui o próprio tráfico interno de pessoas, que se dirigem dos interiores do Brasil, de pequenos municípios, para as grandes metrópoles (Mattos, 2015).

O crescimento desse tipo de crime se deu principalmente, segundo Santos (2015), pelo aumento da importância da indústria têxtil para o mercado interno do país, nas últimas décadas, devido à expansão da classe média e ao acesso das classes inferiores a linhas de créditos, estimulando intensamente o consumo (Palo Neto, 2008). No ano de 2012 a indústria do país criou 1,7 milhões de empregos formais, sendo destes 733.000 mil concentrados nas indústrias de vestuário (Campos, 2015).

Portanto, em razão do Brasil possuir uma indústria têxtil relevante para a sua economia, somado com a facilidade de mão de obra barata dos países latinos (vizinhos) e a necessidade de se tornar mais competitivos diante ao mercar externo, RC: 86328

Link de acesso: https://www.nucleodoconhecimento.com.br/ciencias-sociais/textil-brasileira 
os estrangeiros tornaram-se uma presa fácil para a implantação do sistema de produção citado anteriormente, o sweating system.

O sweating system é uma forma de terceirização que as grandes marcas encontram para diminuir seus custos de produção e, ao mesmo tempo tentar se eximir das responsabilidades trabalhistas.

O referido sistema tem como característica, locais de trabalho que se confundem com residências, nos quais os trabalhadores laboram sob condições deploráveis, sofrendo opressão, recebendo salários miseráveis, tendo jornadas exaustivas e precárias.

Essa forma de trabalho, onde não há o mínimo de respeito com as leis trabalhistas, na qual a remuneração se dá apenas pela produção, também é conhecida como "sistema de suor" (tradução nossa). No Brasil, este tipo de trabalho é mais comum entre trabalhadores estrangeiros (Cristova e Goldschmidt, 2012).

Um dos casos de maior repercussão nos últimos anos ocorreu em 2011, na cidade de Americana, envolvendo a loja "Zara", no Estado de São Paulo, na qual o Ministério Público do Trabalho descobriu 51 pessoas (na maioria bolivianos) trabalhando em condições análogas à escravidão em uma fábrica de roupas fornecedora da grande grife em questão. Os trabalhadores eram submetidos a jornadas extenuantes de até 14 horas diárias, recebendo vinte centavos por peça produzida (Cristova e Goldschmidt, 2012).

Outro caso de grande repercussão foi o envolvimento da rede Pernambucanas que, mesmo após ser investigada nos anos de 2010 e 2011, não quis firmar Termo de Ajustamento de Conduta com o Ministério Público, sendo processada por exploração de mão de obra (Cristova e Goldschmidt, 2012).

No Brasil, o combate a esse tipo de prática se dá principalmente por órgãos públicos como o Ministério Público do Trabalho, Polícia Federal, Governos Federais e Estaduais, e por organizações internacionais, como a OIT, que buscam por intermédio da fiscalização e punição, coibir esse tipo de prática desumana que afeta principalmente estrangeiros latinos americanos, sendo uma maioria considerável RC: 86328

Link de acesso: https://www.nucleodoconhecimento.com.br/ciencias-sociais/textil-brasileira 
advindo da Bolívia, na intenção de fugir das péssimas condições de vida que lá se encontram.

Conforme afirma Mattos (2015), a maioria das pessoas submetidas às condições degradantes de trabalho na indústria têxtil no Brasil é boliviana, que deixam seu país devido à precária situação socioeconômica, corrupção e sistema de governo, já que o país apresenta alguns dos piores indicadores sociais da América do Sul.

Buscando apenas o lucro, as empresas contratam os imigrantes bolivianos e os pagam conforme a produção, submetendo-os a baixos salários, expondo-os a jornadas exaustivas e degradantes, que chegam até 16 horas diárias. Sofrem também com o trabalho forçado, diante de cerceamento de sua liberdade, por meio de dívidas que nascem de cobranças irregulares, ou por estrarem com suas documentações ilegais.

Assim, a mão de obra dos bolivianos atende a necessidade momentânea do setor têxtil, já que são trabalhadores descartáveis, temporários e isolados, sem proteção social, que preenchem adequadamente o vazio de serviços baratos, renegados pelos brasileiros.

O Brasil adota há décadas o combate a esse tipo de prática por meio da união dos governos e organizações não governamentais. E foi por intermédio de fiscalização que muitos casos de bolivianos em condições análogas ao escravo vêm sendo descobertos e combatidos. Um dos casos mais surpreendentes ocorreu no ano de 2011, na cidade de Americana, interior de São Paulo, na qual o Ministério Público do trabalho descobriu 51 pessoas, sendo destes 46 bolivianos, trabalhando em condições análogas à escravidão, de forma degradante e desumana em uma oficina de confecção, que por sua vez havia sido contratada por uma grande loja varejista, a "Zara". Os trabalhadores trabalhavam em média 14 horas por dia e recebiam $R \$ 0,20$ (vinte centavos) por peça de roupa produzida (Cristova e Goldschmidt, 2012).

Outro caso que ganhou bastante repercussão nacional foi envolvendo a grande loja varejista "Marisa", que recebeu 48 autos de infração por manter 16 bolivianos em situação de escravidão contemporânea, na cidade de São Paulo. Os trabalhadores RC: 86328

Link de acesso: https://www.nucleodoconhecimento.com.br/ciencias-sociais/textil-brasileira 
eram submetidos a jornadas de 14 horas diárias, recebendo mensamente apenas $R \$$ 247,00 (duzentos e quarenta e sete reais). Ademais, no local foram encontrados documentos que comprovavam o tráfico dos imigrantes pela fronteira (Campos, 2015).

Não fugindo da maioria da realidade dos outros casos que ocorrem no Brasil, os trabalhadores encontrados na sua maioria eram formados por imigrantes bolivianos, que foram aliciados por meio de promessas de emprego e melhores condições de vida. Porém, ao chegar no Brasil, a realidade era outra. Ficavam presos em um sistema de dívidas, envolvendo principalmente alimentação, transporte e documentação (Mattos, 2015).

\section{CONCLUSÕES}

Devido a sua nova roupagem o trabalho escravo contemporâneo tornou-se invisível por algum tempo, mas com os esforços de organizações internacionais e diversos países, atualmente, ele já foi reconhecido e conceituado, sendo possível o seu combate.

Os fatores que tornam possível a prática desse crime, mesmo que em dias atuais, ele é basicamente relacionado a um tripé: impunidade, pobreza e lucro.

A situação de miséria da população mais carente os força a se submeter a tipos de trabalhos em condições sub-humanas. No caso da indústria têxtil, estes trabalhadores são coagidos por oficinas de costuras, que por sua vez prestam serviços terceirizados para as grandes lojas varejistas, caracterizando o sistema sweating system de produção.

A competitividade de mercado, buscando a qualquer preço a lucratividade, faz com que o setor têxtil submeta os trabalhadores a jornadas de dezesseis horas diárias, em locais insalubres e privados de sua liberdade.

Estes trabalhadores da indústria têxtil são principalmente imigrantes de países vizinhos, subdesenvolvidos, da América Latina. O principal país fornecedor da mão 
de obra é a Bolívia, que tem uma vasta população em situação de miséria, que busca no país vizinho melhores condições de vida.

O Brasil foi um dos primeiros países no mundo a reconhecer este tipo de trabalho, e que de forma conjunta com a Organização Internacional do Trabalho (OIT) e ostras entidades não governamentais procuram combater tal pratica criminosa em seu território.

Portanto, o trabalho escravo ainda é uma realidade no Brasil e no mundo, encontrando no setor têxtil brasileiro condições de se proliferar.

\section{REFERÊNCIAS}

ARAÚJO JÚNIOR, F. M. Dano moral decorrente do trabalho em condição análoga à de escravo: âmbito individual e coletivo. Revista do Tribunal Superior do Trabalho, v. 72, n. 3, p. 87-104, 2006.

AUDI, P. A escravidão não abolida. In: VELLOSO, G. e FAVA, M. N. (Ed.). Trabalho Escravo Contemporâneo: o desafio de superar a negação. São Paulo SP: LTr, 2006.

BALES, K. Gente descartável: A Nova Escravatura na Economia Mundial. Lisboa: Editorial Caminho, 2001.

BRASIL. Lei n. 2.848, de 07 de setembro de 1940. Institui o Código Penal., Brasília DF, 1940. Disponível em: < http://www.planalto.gov.br/ccivil_03/decretolei/Del2848compilado.htm >. Acesso em: 02 de jun. 2018.

Código penal - Decreto-lei no 2.848/1940. TÉCNICAS, C. D. E. Brasília DF: Senado Federal: 138 p. p. 2017.

BRITO FILHO, J. C. M. D. Trabalho com redução do homem à condição análoga de escravo e dignidade da pessoa humana. Genesis: revista de direito do trabalho, v. 23, n. 137, p. 673-682, 2004. 
CAMPOS, L. R. J. D. 0 trabalho análogo à condição de escravo no setor têxtil brasileiro. 2015. 41p. (Especialização). Universidade Tuiuti do Paraná, Curitiba PR.

COSTA, C. Para que serve a 'lista suja' do trabalho escravo? , 2015. Disponível em: $<$

https://www.bbc.com/portuguese/noticias/2015/04/150402_trabalho_escravo_entend a_cc >. Acesso em: 17 jun. 2018.

CRISTOVA, K. G.; GOLDSCHMIDT, R. O trabalho escravo contemporâneo no Brasil. Anais III Simpósio Internacional de Direito: dimensões materiais e eficaciais dos direitos fundamentais. IIISID. Chapecó SC: 24 p. 2012.

DAMIÃO, D. R. R. Situações análogas ao trabalho escravo: reflexos na ordem econômica e nos direitos fundamentais. São Paulo SP: Letras Jurídicas, 2014.

DOU. LEI № 14.946, DE 28 DE JANEIRO DE 2013. São Paulo SP, 2013. Disponível em:

http://dobuscadireta.imprensaoficial.com.br/default.aspx?DataPublicacao=20130129 \&Caderno=DOE-I\&NumeroPagina=1 >. Acesso em: 28 maio 2018.

FAUSTO, B. História do Brasil São Paulo SP: Editora da Universidade de São Paulo, 2004.

GERHARDT, T. E.; SILVEIRA, D. T. Métodos de pesquisa. Porto Alegre RS: Editora da UFRGS, 2009. 120p.

GORENDER, J. O escravismo colonial. São Paulo SP: Ática, 1985.

GRECO, R. Curso de Direito Penal: parte especial. Niterói RJ: Impetus, 2008.

LIMA, T. C. S. D.; MIOTO, R. C. T. Procedimentos metodológicos na construção do conhecimento científico: a pesquisa bibliográfica. Rev. Katál., v. 10, p. 37-45, 2007.

MARTINEZ, L. Curso de Direito do Trabalho: relações individuais, sindicais e coletivas do trabalho. São Paulo SP: Saraiva, 2015. 
MARTINS, S. P. Direito do Trabalho. São Paulo SP: Atlas, 2011.

MATTOS, C. N. S. D. Análise contemporânea do trabalho análogo ao escravo na indústria têxtil. 2015. 56p. (Graduação). Centro Universitário Eurípides de Marília UNIVEM, Marília SP.

MIRANDA, C. C.; OLIVEIRA, L. J. D. Trabalho análogo ao de escravo no brasil: necessidade de efetivação das políticas públicas de valorização do trabalho humano. Revista de Direito Público, v. 5, n. 3, p. 150-170, 2010.

MONTEIRO, L. A. Políticas públicas para erradicação do trabalho escravo contemporâneo no Brasil: Um estudo sobre a dinâmica das relações entre os atores governamentais e não-governamentais. 2011. 184p. (Mestrado). Fundação Getulio Vargas, Rio de Janeiro RJ.

MONTENEGRO, A. T. Reinventando a liberdade: a abolição da escravatura no Brasil. São Paulo SP: Atual, 1997.

MOTA, M. B.; RAMOS, B. P. História das Cavernas ao Terceiro Milênio. São Paulo Sp: Moderna, 1999.

MTE. Quadro geral de operações de fiscalização para erradicação do trabalho escravo - SIT/SRTE - 1995/2010. Brasília DF, 2018. Disponível em: < http://www.mte.gov.br/fisca_trab/quadro_resumo_1995_2010.pdf >. Acesso em: 18 jun. 2018.

NASCIMENTO, A. M. Curso de Direito do Trabalho. São Paulo SP: Saraiva, 2010.

OLIVEIRA, J. S. D. O trabalho escravo conteporâneo no Brasil. 2011. 50p. (Especialização). Universidade Anhanguera-Uniderp, Fortaleza CE.

PALO NETO, V. Conceito jurídico e combate ao trabalho escravo contemporâneo. São Paulo SP: LTr, 2008. 128p.

PINSKY, J. Escravidão no Brasil. São Paulo SP: Contexto, 1992. 
PRADO, A. A. Trabalho escravo hoje. Brasília DF, 2005. Disponível em: < https://www.anamatra.org.br/artigos/863-trabalho-escravo-hoje-09477223427479363 >. Acesso em: 15 jun. 2018.

PRONER, A. L. Neoescravismo: análise Jurídica das Relações de Trabalho. Curitiba PR: Juruá, 2010.

RODRIGUEZ, P. A. D. S. Princípios Constitucionais aplicado ao Direito do Trabalho: Colisão de Princípios nos casos concretos. 2015. 49p. (Especialização). Universidade Federal do Rio Grande do Sul, Porto Alegre RS.

SARAIVA, R. Direito do Trabalho. São Paulo SP: Método, 2012.

SILVA, J. B. D. Trabalho escravo rural no brasil contemporâneo - uma ofensa à dignidade humana. 2009. 45p. (Especialização). Instituto Brasiliense de Direito Público, Brasília DF.

SILVA, M. R. D. Trabalho análogo ao de escravo rural no Brasil do século XXI: novos contornos de um antigo problema. 2010. 280p. (Mestrado). Universidade Federal de Goiás, Goiânia GO.

SIMÓN, S. L.; MELO, L. A. C. D. Direitos humanos fundamentais e trabalho escravo no Brasil. São Paulo SP: LTr, 2007.

SOARES, S. F. Notas estatisticas sobre a producção agricola e carestia dos generos alimenticios no Imperio do Brazil. Rio de Janeiro RJ, 1860. Disponível em: < http://www2.senado.leg.br/bdsf/handle/id/221678 >. Acesso em: 20 jun. 2018.

Enviado: Maio, 2021.

Aprovado: Maio, 2021. 